Pamiętnik Literacki 2012, 3, s. 195-209
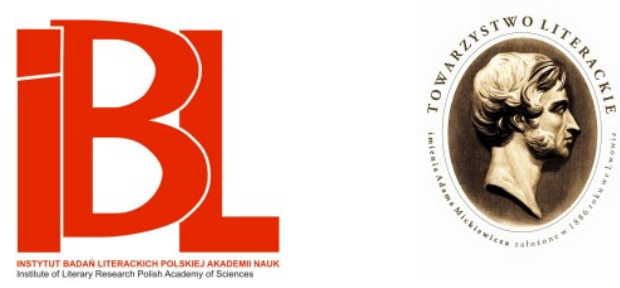

Dwie zapomniane powieści uniwersyteckie

Przyczynek do dziejów realizmu socjalistycznego

$$
\text { w Polsce }
$$

Jerzy Smulski 
Pamiętnik Literacki CIII, 2012, z. 3

PL ISSN 0031-0514

JERZY SMULSKI

(Uniwersytet Mikołaja Kopernika, Toruń)

\section{DWIE ZAPOMNIANE POWIEŚCI UNIWERSYTECKIE PRZYCZYNEK DO DZIEJÓW REALIZMU SOCJALISTYCZNEGO W POLSCE}

Powieść uniwersytecka to gatunek, który w literaturze zachodniej zrobił w ciągu ostatniego półwiecza sporą karierę, na co dowodem popularność takich autorów, jak Kingsley Amis, Malcolm Bradbury czy - przede wszystkim - David Lodge ${ }^{1}$. Zupełnie odmiennie sytuacja przedstawia się w literaturze polskiej; jest to gatunek niemal nie istniejący $\mathrm{i}$ - co ściśle się z tym wiąże - nie będący przedmiotem refleksji badawczej ${ }^{2}$.

Tym bardziej godne analizy wydają się zatem dwa socrealistyczne utwory, realizujące ów wzorzec gatunkowy; zupełnie zapomniane nie tylko przez czytelników, ale i przez historyków literatury. Próżno szukać o tych dziełach wzmianki czy to w monografii Zbigniewa Jarosińskiego Nadwiślański socrealizm, przynoszącej gruntowne omówienie polskiej prozy socrealistycznej, czy to w Słowniku realizmu socjalistycznego, w którym często - jako egzemplifikacje - pojawiają się teksty drugorzędne ${ }^{3}$.

Problematyka uniwersytecka (albo - określmy rzecz inaczej - studencka) ma w polskiej literaturze socrealistycznej charakter marginalny; wszak dwa utwory to ułamek obfitej produkcji pisarskiej lat 1949-1955. Wydaje się, że podobnie sprawa wygląda w literaturze radzieckiej, gdzie do powieści uniwersyteckich można zaliczyć Studentów Jurija Trifonowa, Uniwersytet Grigorija Konowałowa oraz Żenię Masłowa i Trzech w szarych płaszczach Władimira Dobrowolskiego, a więc znów stosunkowo niewiele tekstów ${ }^{4}$.

Wróćmy wszakże do literatury polskiej. Warto przy tej okazji sformułować

1 Zob. E. K r a s k o w s k a, Powieść uniwersytecka. „Arkusz” 1993, nr 15. - W. N o w i c k i, Campus novel. Hasło w: Stownik rodzajów i gatunków literackich. Red. G. Gazda, S. Tynecka-Makowska. Kraków 2006.

2 Wyjątek stanowi szkic E. K ra s k ow s k i e j Dlaczego lubimy czytać powieści uniwersyteckie, a nie lubimy ich pisać? („Pogranicza” 2008, nr 2); za wymowny można uznać brak artykułu o polskiej powieści uniwersyteckiej w tomie Kampus. Pisarstwo literaturoznawców (Red. J. Madejski. „Litteraria Copernicana” 2010, nr 1).

3 Z. J a r o s iń s k i, Nadwiślański socrealizm. Warszawa 1999. - Słownik realizmu socjalistycznego. Red. Z. Łapiński, W. Tomasik. Kraków 2004.

4 Zob. T. D r e w no w s k i, Kuźnia młodych charakterów. W: J. Tri fo n o w, Studenci. Przeł. T. E v e r t. Warszawa 1953. Oprócz tego utworu na język polski przetłumaczona została także powieść W. D o b row o ls k i e g o Trzej w szarych płaszczach (Przeł. J. B r o d zk i. Warszawa 1950). 
jeszcze następującą obserwację: nie tylko tematyka uniwersytecka nie jest w niej obficie reprezentowana, ale i w ogóle problematyka szkolna. W gruncie rzeczy szerzej ukazuje się ją jedynie w Obywatelach Kazimierza Brandysa. Może to zaskakiwać, bo jedną z częściej pojawiających się (albo wręcz: naczelną) w literaturze socrealistycznej była metafora świata jako szkoły (schola vitae) i związane z nią role fabularne: ucznia, nauczyciela i fałszywego nauczyciela ${ }^{5}$. Jak widać, nie skutkowało to jednak lokowaniem akcji w placówkach edukacyjnych (czy na uniwersytecie).

Dwie ,zapomniane powieści”, o których mowa w tytule tego szkicu, to Herkulesy Jerzego Stefana Stawińskiego i Inauguracja Zdzisława Wróbla. Pierwsza z nich ukazała się w 1953 r. (a następnie została dwukrotnie wznowiona: w 1954 i 1955 r.), druga - w 1954 roku.

W wypadku Stawińskiego jest to drugi jego - po powieści Światto we mgle (1952) - utwór. O randze Stawińskiego jako pisarza decyduje przede wszystkim dorobek scenariuszowy tego współautora najważniejszych filmów „,szkoły polskiej”: Kanału Andrzeja Wajdy oraz Człowieka na torze, Eroiki i Zezowatego szczęścia Andrzeja Munka.

Inauguracja to również drugie dzieło Wróbla; pierwszym był dramat Dobroczyńcy, powstały w 1953 r. i wyróżniony w konkursie Ministerstwa Kultury i Sztuki oraz Związku Literatów Polskich na utwór sceniczny poświęcony 10-leciu Polski Ludowej. Wróbel należy jednak dziś - w przeciwieństwie do Stawińskiego - do autorów zapomnianych. Wydał później kilka tomów prozy, napisał parę dramatów, ostatnie zaś lata życia (zmarł w r. 2007) poświęcił historii erotyzmu w literaturach i kulturach świata, co zaowocowało m.in. 5-tomową publikacją Dzieje erotyzmu (Bydgoszcz 1998-2003).

Co istotne, akcja obu powieści rozgrywa się w uczelniach utworzonych już w Polsce Ludowej. W Herkulesach toczy się w Akademii Medycznej w Białymstoku, w Inauguracji - na Uniwersytecie Mikołaja Kopernika w Toruniu (choć w powieści Wróbla ani razu nie pojawia się nazwa miasta ani uniwersytetu, do czego jeszcze powrócę). Fakt ten - nawet jeśli uznać go za dzieło przypadku wydaje się symptomatyczny, ówczesne władze przywiązywały bowiem dużą wagę do rozwoju szkolnictwa wyższego, a więc - eo ipso - tworzenia nowych uczelni. W roku 1945 premier Edward Osóbka-Morawski zapowiadał rozbudowę sieci szkół wyższych, kładąc równocześnie nacisk na decentralizację ośrodków naukowych ${ }^{6}$. Ostatecznie powołano 4 nowe uniwersytety: w Lublinie, Łodzi, Wrocławiu (choć tam, rzecz jasna, istniał od 1702 r. uniwersytet niemiecki) i w Toruniu; zapewne o każdej z tych lokalizacji w jakiejś mierze decydowały przesłanki polityczne.

W wypadku Torunia - gdzie uniwersytet utworzony został na mocy dekretu Krajowej Rady Narodowej z 24 VIII $1945^{7}$ - istotną rolę odgrywały wszakże

5 Zob. W. To m a s i k, Produkcyjna powieść. Hasło w: Stownik literatury polskiej XX wieku. Red. A. Brodzka [i in.]. Wrocław 1992.

6 Zob. J. C h o d a k o w s k a, Rozwój szkolnictwa wyższego w Polsce Ludowej w latach 19441951. Wrocław 1981, s. 56. - S. M a u e r s b e r g, Nauka i szkolnictwo wyższe w latach 1939-1951. W zb.: Historia nauki polskiej. T. 5: 1918-1951, cz. 1. Red. Z. Skubała-Tokarska. Wrocław 1992, s. $412 \mathrm{n}$.

7 Pierwsza immatrykulacja studentów odbyła się 25-27 XI 1945, natomiast pierwsza inaugu- 
czynniki pozapolityczne. Było to miasto o tradycjach naukowych (Towarzystwo Naukowe, Książnica Miejska, Instytut Bałtycki); późną wiosną tego roku znalazła się tam liczna grupa pracowników (w tym znanych profesorów) Uniwersytetu Stefana Batorego w Wilnie, którzy przybyli do Torunia wraz z rodzinami w pociągach repatriacyjnych ${ }^{8}$. Nadto miasto to nie zostało zniszczone w wyniku działań wojennych, a zatem sporo gmachów można było przekazać niemal od razu na użytek uczelni ${ }^{9}$.

Nieco inaczej sprawa przedstawiała się z Akademią Medyczną w Białymstoku. Jej utworzenie związane było w jakiejś mierze z reformą szkolnictwa medycznego, polegającą na przekształceniu wydziałów lekarskich 6 uniwersytetów w samodzielne akademie lekarskie (rozporządzeniem Rady Ministrów z 24 X 1949) ${ }^{10}$. Wcześniej takie uczelnie powołano w Gdańsku (8 X 1945), Bytomiu i Szczecinie (obie 20 III 1948). Akademia Medyczna w Białymstoku (założona na mocy rozporządzenia Rady Ministrów z 3 II $1950^{11}$ ) była zatem dziesiątą uczelnią tego typu w Polsce; w efekcie powstała sieć równomiernie rozmieszczonych wyższych szkół medycznych, które sprawowały specjalistyczny nadzór nad służbą zdrowia w poszczególnych regionach ${ }^{12}$. System ów - dodajmy na marginesie - spetryfikował się do tego stopnia, że kolejną nową akademię medyczną założono w Bydgoszczy dopiero w 1984 roku.

Uczelnia utworzona została w mieście, które - w przeciwieństwie do Torunia - nie miało bogatej tradycji życia intelektualnego. W okresie międzywojennym istniało w Białymstoku jedynie szkolnictwo średnie oraz - w latach 1919-1936

racja roku akademickiego 5 I 1946. Zob. L. K o l a n k o w s k i, Pierwsze trzy lata istnienia UMK (1945-1948). Garść wspomnień pierwszego Rektora z okresu organizacyjnego. Do druku przygotowała S. G ro ch ow in a. W zb.: Ludwik Kolankowski (1882-1956). W pięćdziesiąta rocznicę śmierci. Red. W. Sieradzan. Toruń 2006, s. 65, 75.

${ }^{8}$ Zob. J. B ełk o t, Uniwersytet Mikołaja Kopernika w Toruniu w latach 1945-1985. Toruń 1986, s. 25 n.

${ }^{9}$ Zob. M. P s z c zół k o w s k i, Architektura Uniwersytetu Mikołaja Kopernika. Toruń 2009.

${ }_{10} \mathrm{~W}$ polskich środowiskach intelektualnych fakt ten potraktowano jako symptom sowietyzacji szkolnictwa wyższego. W. K u la pisał do żony: „Oczywiście jest to upodobnienie do ZSRR. [...] Ale w ogóle wydaje mi się to ciosem śmiertelnym (być może, że koniecznym) dla idei dawnych universitates" (cyt. za: M. K u la, Mimo wszystko. Bliżej Paryża niż Moskwy. Książka o Francji, PRL $i$ o nas, historykach. Warszawa 2010, s. 534). Na temat politycznych okoliczności utworzenia akademii białostockiej obszerniej piszą A. P a s k o i P. Ła piń s k i (Białystok wlatach 1944-1956. W zb.: Historia Białegostoku. Red. A. Dobroński. Białystok 2012, s. 487-488).

${ }_{11}$ Dodajmy, że od 1955 r. akademia nosiła imię Juliana Marchlewskiego, czego wszakże nie regulował żaden przepis prawny (zob. A. K o c h a ń s k i, Polska 1944-1991. Informator historyczny. T. 1: Podziat administracyjny, ważniejsze akty prawne, decyzje i enuncjacje państwowe 〈19441956). Warszawa 1996, s. 311); jako patrona brano też pod uwagę Feliksa Dzierżyńskiego (zob. W. Ło t o ck i, Wspomnienia i refleksje. Szkic autorski na Jubileusz Pięćdziesięciolecia Uczelni. W zb.: Pót wieku Akademii Medycznej w Białymstoku 1950-2000. Oprac. i wybór materiałów K. Wo r o w s ki. Białystok 2000, s. 359).

12 Zob. C h od a k o w s k a, op. cit., s. 161. Ulokowanie akademii w Białymstoku (w grę wchodził także Olsztyn), wiązało się z faktem, iż ta część Polski była najbardziej zaniedbana pod względem sanitarnym (zob. T. K i e la n o w s k i, Powstanie i organizacja Akademii Medycznej w Biatymstoku. W 30 rocznice powstania Akademii Medycznej w Białymstoku. W zb.: Pół wieku Akademii Medycznej w Białymstoku 1950-2000, s. 312-313). Literackim refleksem zlokalizowania akademii w Białymstoku jest wiersz W. Wor o s z y l s ki e go Białystok(w: A. B ra un, A. M a n d a li a n, W. W o r o s z y l s k i, Wiosna sześciolatki. Wiersze. Warszawa 1951). 
- Seminarium Nauczycielskie im. Króla Zygmunta Augusta ${ }^{13}$; nie podejmowano oficjalnych prób założenia wyższej uczelni ani nie miały tam siedziby żadne instytucje naukowe ${ }^{14}$. Nadto brak było kadry, bo przedwojenni profesorowie - chodzi przede wszystkim o uczonych zatrudnionych dotąd na wydziałach lekarskich uniwersytetów w Wilnie i we Lwowie - podjęli już pracę na innych uczelniach. Akademia miała zatem powstać - jak to określił jeden z jej pierwszych profesorów, Tadeusz Dzierżykray-Rogalski - „prawie na pustyni” ${ }^{15}$.

Przyjrzyjmy się zajmującym nas powieściom.

Rozważania rozpoczniemy od Inauguracji. Akcja utworu rozgrywa się w uniwersyteckim mieście, którego nazwa nie pojawia się w powieści (z wyjątkiem informacji metatekstowej o czasie i miejscu powstania dzieła: „Warszawa-Toruń 1952-1954” (I 308) ${ }^{16}$. Topograficzne realia są opisane z fotograficzną wręcz ścisłością; w owym mieście znajduje się „ratusz z płaską wieżą, pomnik Kopernika z globusem w ręku i szczątki średniowiecznych murów" (I 166), o bohaterze zaś czytamy:

Minął zabytkowy ratusz o płaskiej, czworokątnej wieży i skręcił w wąską, ciemną uliczkę pomiędzy kościołem panny [!] Marii i wysokim murem więziennym. [I 200]

Akcja rozpoczyna się pod koniec września 1947; trwają przygotowania do inauguracji roku akademickiego na miejscowym uniwersytecie. Pierwsze zdarzenie, o którym dowiaduje się czytelnik, związane jest z działaniami wroga klasowego. Wychodzący z domu studenckiego pozytywny bohater, Zbyszek Wójcik, spostrzega, że ktoś zniszczył dekorację:

Szkło portretu Stalina było rozbite, a papier rozdarty, zupełnie jakby ktoś uderzył weń kamieniem.

Poszedł wolno w stronę gmachu [...] i wtedy zauważył na murze niezdarny napis wymalowany czarną farbą: „Precz z żydo-komuną" ${ }^{17}$. [I 6]

W monologu wewnętrznym głównego bohatera padają istotne pytania, na które odpowiedź przynosi lektura powieści:

A kto jest teraz wrogiem? Profesor, który ma uczyć, wychowywać, uzbrajać w wiedzę na całe życie? Student - kolega z jednej ławki, jednego pokoju? Kobieta, do której wyrywa się serce? [I 203]

Otóż jako wrogowie jawią się - odpowiedzmy na te pytania - i koledzy, i pro-

${ }^{13}$ Gmach, w którym mieściło się seminarium, został w 1950 r. przekazany Akademii Medycznej; ma w nim do dziś swą siedzibę Collegium Primum.

${ }^{14}$ Zob. A. Dobrońs ki, Białystok. Historia miasta. Białystok 2001, s. 127, 146-148. J. O n i s z c z u k, T. W i śn i e w s k i, Białystok między wojnami. Opowieść o życiu miasta 19181939. Łódź 2011, rozdz. Oświata. - A. L e c h o w s k i, Białystok w latach 1864-1939. W zb.: Historia Biategostoku, s. 374-380.

15 T. D z i e r ż y k r a y - R o g a $1 \mathrm{~s}$ k i, Pierwszy rok Akademii Medycznej w Biatymstoku. W zb.: Pół wieku Akademii Medycznej w Białymstoku 1950-2000, s. 311.

${ }_{16}$ Skrótem I oznaczam cytaty z powieści Z. W r ó b la Inauguracja (Warszawa 1954), natomiast skrótem H odsyłam do utworu J. S. S t a w iń s k i e g o Herkulesy (Warszawa 1953). Liczby po skrótach wskazują stronice.

17 Tego rodzaju napisy istotnie pojawiały się na murach uczelni. Zob. Powstanie i pierwsze dziesięć lat Uniwersytetu Mikołaja Kopernika 1945-1956. Wybór źródet. Wyd. H. D u c z k o w s k a - M or a c z e w s k a. Toruń 1995, s. 199, 202. 
fesorowie, i kobiety bliskie sercu. Powieść Wróbla przedstawia całą galerię wrogów. Wymieńmy najważniejszych z nich. Student Zwardoń, który uszkodził portret Stalina, następnie zaś dokonał zamachu na sekretarza uczelnianego komitetu PPR, Jerzego Barendę, okazuje się synem lokalnego prezesa PSL-u, który na początku 1947 r. ,szkalował naszą [tj. komunistyczną] władzę i agitował za Mikołajczykiem” (I 147). Ksiądz Zawistowski, duszpasterz akademicki, inspirujący studencki strajk i współdziałający ze zbrojnym podziemiem. Cybajtis, oficer armii Andersa, powracający do kraju, by w mundurze pułkownika Wojska Polskiego kierować antykomunistyczną organizacją. Profesor Nierojewski, należący do tych wykładowców, którzy z katedr głoszą „wsteczne, antynaukowe teorie idealistyczne” (I 114). I wreszcie ,wilk w owczej skórze” - Szulski, przewodniczący Akademickiego Związku Walki Młodych, który ukrywa, że jest synem komendanta granatowej policji w Białymstoku; w czasie wojny działał w Narodowych Siłach Zbrojnych i brał udział w mordowaniu AL-owskich partyzantów, a teraz pomaga w próbie zabójstwa Barendy.

Z nimi walczą pozytywni bohaterowie. Tu trzeba wymienić wspomnianego już studenta historii Zbyszka Wójcika, który trafia na uniwersytet z wojska, najpierw jako student tzw. kursu przygotowawczego (czy: wstępnego) ${ }^{18}$. Warte odnotowania jest pochodzenie społeczne Zbyszka. Jego matka:

Celina Wójcikowa, wdowa po bezrobotnym, wynosiła nocniki spod mieszczańskich panienek, a swemu synowi ukradkiem podawała na schodach ochłapy z pańskiego stołu. [I 95]

Na zebraniu AZWM Zbyszek tak przedstawia swój życiorys:

Ojciec mi umarł jeszcze przed wojną... na gruźlicę... [...] matka zginęła w Kowlu od niemieckiej bomby w czterdziestym trzecim. Miałem wówczas dziewiętnaście lat. Wstąpiłem do wojska. Przeszedłem w pierwszej linii cały szlak bojowy, aż do Kołobrzegu. Tam zostałem ranny. W lewą rękę. Został mi nawet jeszcze odłamek tu w ramieniu... [I 179]

Bohater z taką przeszłością musi opowiedzieć się po właściwej stronie. I tak jest w istocie. Komunistyczna organizacja młodzieżowa okazuje się dlań rodziną ideologiczną, a także niejako zastępczą ${ }^{19}$ :

nie potrafiłem sobie wyobrazić, jak będę żył, gdy wyjdę z wojska, sam, bez rodziny, bez domu, bez niczego, w jednej koszuli... [...] i znalazłem rodzinę.

$[\ldots]$

- Tą rodziną jesteście wy - ZWM. [I 180]

Podobnie rzecz wygląda w wypadku Jerzego Barendy: w czasie okupacji więzień obozu koncentracyjnego, po zakończeniu wojny wstępuje do Polskiej Partii Robotniczej.

Wszystko - inaczej w socrealistycznej powieści być nie może - kończy się zwycięstwem dobra. Wrogowie zostają zdemaskowani i ukarani, a pozytywni bohaterowie rozwiązują swe życiowe problemy: Zbyszek Wójcik postanawia wstąpić do PPR, Barendzie zaś udaje się przeżyć zamach, a jego żona, która do-

${ }^{18}$ Kursy wstępne - wprowadzone dekretem z 24 V 1945 - miały na celu „udostępnienie szkół wyższych młodzieży pochodzącej z zaniedbanych kulturowo środowisk robotniczych i chłopskich” (M a u e r s be rg, op. cit., s. 432).

19 Zob. M. H irs z ow i c z, Pułapki zaangażowania. Intelektualiści w stużbie komunizmu. Warszawa 2001, s. 75. 
tychczas nie zawsze go rozumiała, przechodzi metamorfozę. W finałowej scenie wyznaje ona:

- Ja też chcę służyć tej wielkiej, ludzkiej sprawie [tj. idei komunistycznej]. Tak jak potrafię, w miarę mych sił. I gdy mówiłam, że pragnę ci pomagać, to właśnie to miałam na myśli. [I 307]

Walka klasowa to stały element każdej powieści socrealistycznej; w jej odmianie uniwersyteckiej polega m.in. na starciu studentów (na których, cytuję świetne sformułowanie Michała Głowińskiego, „spłynęła łaska ideologicznej słuszności”20) ze starą kadrą profesorską, głoszącą - jak już wiemy - „wsteczne, antynaukowe teorie idealistyczne". Do owej starej kadry należy profesor historii literatury, Łysogórski, który ,już trzeci miesiąc analizuje faszystowskie dramaty i powieścidła Kadena-Bandrowskiego" (I 265). Jej przedstawicielem jest też profesor Nierojewski, który, mówiąc na wykładzie o XVI-wiecznym buncie żaków w Krakowie, de facto nawołuje studentów do poparcia strajku uniwersyteckiego, zorganizowanego przez wrogów ustroju (z inspiracji wspomnianego tu księdza Zawistowskiego) ${ }^{21}$. Podobną wymowę ma wystąpienie profesora na zebraniu Sodalicji Mariańskiej, w którym historię Polski (i Europy) przedstawił on jako obronę Kościoła i zachodniej cywilizacji przed wschodnim barbarzyństwem (dodajmy, że - w świetle ówczesnych standardów - już same kontakty z Sodalicją byłyby dla Nierojewskiego kompromitujące).

Ciekawe są też lektury bohaterów pozytywnych i negatywnych; wydają się one tym bardziej istotne, że akcja rozgrywa się w środowisku intelektualnym ${ }^{22}$. Zacznijmy od lektur wroga. Oto zebranie Sodalicji Mariańskiej:

Siostra Aniela przyniosła z kancelarii plik gazet i broszur i rozłożyła je na stole. Były to przeważnie stare numery „Rycerza Niepokalanej” i „Tygodnika Powszechnego”, wśród których zawieruszyło się kilka egzemplarzy „Głosu Anglii” i „Gazety Ludowej”, a z broszur Quadragesimo Anno i Fenomenologia wstydliwości księdza Sawickiego. [I 126]

Tytuły periodyków nie wymagają komentarza (choć dziwne wrażenie robi dzisiaj traktowanie „Rycerza Niepokalanej” al pari z ,Tygodnikiem Powszechnym”). Z wyjątkiem - być może - „Głosu Anglii”; było to czasopismo w języku polskim wydawane w latach 1946-1949 w Krakowie przez brytyjskie Ministerstwo Spraw Zagranicznych. Broszury zaś to encyklika papieża Piusa XI, ogłoszona w r. 1931, zawierająca potępienie socjalizmu i komunizmu, oraz niewielka książeczka księdza Franciszka Sawickiego (nosząca wymowny podtytuł: Z problemów moralności seksualnej), której pierwsza edycja ukazała się w Warszawie w 1938 roku. Jej autor utrzymywał, że zanik poczucia wstydliwości jest symptomem degradacji moralnej człowieka ${ }^{23}$.

${ }^{20}$ M. G ło w i ń s k i, Niby-groteska (,, Wojna skuteczna” Jerzego Andrzejewskiego). W: Rytuat i demagogia. Trzynaście szkiców o sztuce zdegradowanej. Warszawa 1992, s. 73.

${ }^{21}$ Do próby wywołania studenckiego strajku w Toruniu istotnie doszło w maju 1946. Zob. Powstanie i pierwsze dziesięć lat Uniwersytetu Mikołaja Kopernika 1945-1956, s. 155. - D. J abłoń s k a - F r ą c k o w i a k, Na Uniwersytecie Mikołaja Kopernika w latach 1946-1966. Wspomnienia fizyka. Red. C. Łubieńska-Iwaniszewska. Toruń 2006, s. 24.

${ }_{22} \mathrm{Na}$ temat lektur bohaterów powieści socrealistycznej zob. M. P i e k a ra, Doświadczenia lekturowe postaci powieści produkcyjnych. W zb.: Presja i ekspresja. Zjazd szczeciński i socrealizm. Red. D. Dąbrowska, P. Michałowski. Szczecin 2002.

${ }^{23}$ Zob. R. P o la k, Sawicki Franciszek. Hasło w: Powszechna encyklopedia filozofii. Red. A. Maryniarczyk [i in.]. T. 8. Lublin 2007, s. 933-934. 
W zebraniach Sodalicji uczestniczy studentka historii, Elżbieta, przedstawiona w powieści jako sfanatyzowana dewotka ${ }^{24}$; czytuje ona prozę François Mauriaca, a zatem czołowego francuskiego pisarza katolickiego ${ }^{25}$.

Do lektur Zwardonia należą powieści publikowane przez wydawnictwo $\mathrm{Cu}-$ krowskiego ${ }^{26}$ oraz Ulina Mała Józefa Piłsudskiego.

Ciekawe są również książki przywoływane przez studentkę historii Luśkę Putkównę ${ }^{27}$, drobnomieszczankę, córkę właściciela restauracji (w czasie okupacji - volksdeutscha). Czyta ona Towarzysza Victora Margueritte'a; jest to - przypomnijmy - kontynuacja głośnej w latach dwudziestych Chłopczycy (1922), traktowanej wówczas jako „manifeścik swobody erotycznej” ${ }^{28}$. Ten tytuł nie może dziwić, skoro Luśka to „dziewczyna wolna od przesądów” - owa peryfraza (pojawiająca się także w Obywatelach Brandysa ${ }^{29}$ ) oznacza w literaturze socrealistycznej osobę o swobodnych obyczajach erotycznych. Rozwój fabuły pokazuje, że w istocie Putkówna to panna - użyjmy formuły potocznej - ,puszczalska" 30 (a trzeba pamiętać, iż seks w literaturze socrealistycznej uprawia przede wszystkim wróg klasowy). Luśka słyszała wszakże i o literaturze ambitniejszej: „Moje życie jest jak to sartrowskie piekło [...], mały pokój o drzwiach zamkniętych" (I 259)-mówi do Zbyszka. Znajomość dramatów Jeana-Paula Sartre'a ${ }^{31}$ nie koresponduje z jej naiwnymi marzeniami o przyszłości:

Chciałabym być sławną, jak Lukrecja Borgia albo jak Maria Stuart, albo jak Rita Hayworth. Być kochaną z bezgranicznym poświęceniem i odpłacać tym samym, nienawidzić i walczyć. Przeżywać wielkie namiętności, pokonywać poważne przeszkody, no w ogóle żyć i używać pełną piersią. Nie znoszę przeciętności, szarzyzny, powszedniości. [I 260]

Zupełnie odmienne są lektury postaci pozytywnych. Jedna z nich, student historii Żak, członek AZWM, mówi: „Trzeba czytać »Kuźnicę«, »Odrodzenie«, różne broszury, których ukazuje się coraz więcej, Marksa, Engelsa, Lenina. Bez tego nie ujedziesz" (I 114-115). Prace klasyków marksizmu studiuje główny bohater powieści, Jerzy Barenda:

${ }^{24}$ Z. P ę d zi ń s ki (Z. P., Czytać - nie czytać? „Dziś i Jutro” 1955, nr 20, s. 5), recenzując Inauguracje w wydawanym przez PAX tygodniku, tak komentował kreowanie przez jej autora postaci związanych z Kościołem: „Metoda pisarska Wróbla jest w tym wypadku prosta: robienie z przeciwników ideowych łajdaków i durniów i tylko łajdaków i durniów. Ta metoda, każąca nieodmiennie studenta-katolika [...] wiązać z reakcją, sabotażem, kradzieżą i zbrodnią, ma niewiele wspólnego z realizmem".

${ }_{25}$ Odnotujmy, że autorem niewielkiej monografii o Mauriacu był K. Górski (François Mauriac. Studium literackie. Poznań 1935), w latach 1945-1965 profesor UMK, uważany przez gremia partyjne za klerykała i czołowego reakcjonistę (toteż w latach 1950-1956 odsunięty od dydaktyki). Zob. Powstanie i pierwsze dziesięć lat Uniwersytetu Mikołaja Kopernika 1945-1956, s. 198.

${ }_{26}$ Wydawnictwo Stanisława Cukrowskiego publikowało literaturę bardzo zróżnicowaną, w tym także utwory popularne, np. autorstwa H. Courths-Mahler czy I. Zarzyckiej. Zostało zatem przywołane jako wydawca tandety; wszak z powieści Wróbla dowiadujemy się, że Zwardoń czyta ,szmirę” (I 253).

${ }^{27}$ Można sądzić, że jest to nazwisko znaczące - ze względu na podobieństwo do hiszpańskiego słowa: ,puta" 'dziwka'.

${ }^{28}$ L. E u s t a c h i e w i c z, Między wspótczesnością a historią. Warszawa 1973, s. 116.

${ }^{29}$ K. B r a n d y s, Obywatele. Warszawa 1954, s. 136.

${ }^{30}$ Dodajmy, że jest to postać skonstruowana dość sugestywnie; A. B i e r n a c k i w recenzji Inauguracji (Prawda mimo woli. „Twórczość” 1955, nr 9, s. 166) pisał: „Udała się [autorowi] zwłaszcza rozwydrzona drobnomieszczanka, Luśka [...]”.

${ }^{31}$ Sam fakt odwołania się do twórczości Sartre'a w powieści wydanej w 1954 r. jest jednak chyba czymś niezwykłym, bo jego popularność zaczęła się w Polsce nieco później. 
W ostatnich latach Jerzy nabrał lekceważącego stosunku do beletrystyki. Odkąd zaczął wgryzać się w dzieła Marksa i Engelsa i studiować prace Lenina i Stalina, wydawało mu się, że lektura powieści byłaby dla niego niepotrzebną stratą czasu. [...] Uważał, że prawdziwy komunista nie powinien się roztkliwiać nad wymyślonymi przez pisarzy losami bohaterów i wstydził się tego, że kiedyś z takim wzruszeniem pochłaniał powieści Sienkiewicza, Prusa i Żeromskiego. [I 241]

Dopiero lektura powieści Nikołaja Ostrowskiego Jak hartowała się stal sprawia, że Barenda odnajduje sens czytania beletrystyki, Opowieść o prawdziwym człowieku Borysa Polewoja zaś intensywnie mobilizuje go do dalszej walki. I dla Barendy, i dla jego żony, Wandy, ważną książką są pamiętniki Feliksa Dzierżyńskiego; pod ich wpływem Wanda przeżywa przemianę wewnętrzną i opowiada się po właściwej stronie.

Dotychczasowe uwagi świadczą o tym, że Inauguracja jest schematyczną powieścią socrealistyczną, której akcja została zlokalizowana w środowisku akademickim. Łatwo odpowiedzieć na pytanie, skąd autor czerpał wiedzę o szczegółach życia uniwersyteckiego. Otóż Zdzisław Wróbel był w latach 1947-1951 studentem romanistyki i rusycystyki na Uniwersytecie Mikołaja Kopernika, działaczem PPR (później PZPR), członkiem AZWM (a nawet przewodniczącym Zarządu Okręgowego) ${ }^{32}$. Znajomość realiów, również personalnych, wykorzystał w tym stopniu, że opublikowaniu Inauguracji towarzyszyła w Toruniu - jak odnotował autor pośmiertnego wspomnienia o pisarzu - ,atmosferka skandaliku, ponieważ jej bohaterami były łatwe do rozszyfrowania i nie zawsze pozytywnie naszkicowane postacie naukowego środowiska UMK" 33 .

Na podstawie innych źródeł ${ }^{34}$ można sądzić, iż nie była to ,,atmosferka skandaliku", lecz wielki skandal, bo klucz - z pewnymi wyjątkami - był wówczas nad wyraz czytelny (a i dzisiaj nie jest przesadnie trudny do odgadnięcia).

Zacznijmy od postaci epizodycznych. Profesor Łysogórski (analizujący - przypomnijmy - na zajęciach ,faszystowskie” utwory Kadena-Bandrowskiego) to

${ }^{32}$ Zob. B. Ty s z k i e w i c z, Wróbel Zdzisław. Hasło w: Współcześni polscy pisarze i badacze literatury. Słownik biobibliograficzny. Oprac. zespół pod red. J. Czachowskiej i A. Szałagan. Warszawa 2004, s. 296. Wkrótce po publikacji Inauguracji sam autor tak wypowiadał się na temat genezy swej powieści: „Jeszcze w czasie studiów na Uniwersytecie Mikołaja Kopernika czułem potrzebę jakiegoś uzewnętrznienia tych konfliktów, przeżyć i zmagań, w których brałem udział" (Wł. K., Rozmowa z autorem [,,Inauguracji”]. „Nowy Tor” 1955, nr 5 , s. 2). W odpowiedzi zaś na pytanie dziennikarza: „Jest to więc powieść o Uniwersytecie Mikołaja Kopernika?”, stwierdzał: „Takie określenie byłoby niezupełnie ścisłe. Po pierwsze dlatego, że jak już wspomniałem wyżej, nie miałem zamiaru napisać powieści »o uniwersytecie«, lecz o przeżyciach różnych ludzi, związanych w pewnym okresie swego życia z wyższą uczelnią, po drugie - ponieważ starałem się nadać przedstawionym w powieści postaciom cechy uogólniające, typowe nie tylko dla tego okresu i środowiska. Zgodnie z założeniem realizmu socjalistycznego starałem się skupić uwagę na konfliktach najistotniejszych i najbardziej charakterystycznych. Jasne więc, że chociaż opierałem się na faktach i wydarzeniach, które w istocie miały miejsce bądź na Uniwersytecie Mikołaja Kopernika, bądź na innych uczelniach, to jednak nie trzymałem się ich ściśle".

33 Z. J ę d r z y ń s k i, Dociekliwy pisarz i przyjazny człowiek. „Nowości” 2007, nr 287, s. 13; autor tego wspomnienia zna realia, o których w powieści mowa, z autopsji, ponieważ w latach 1951-1955 studiował na UMK polonistykę (a następnie - do 1960 r. - był asystentem w Katedrze Historii Literatury Polskiej). O Inauguracji jako o powieści z kluczem wspomina $\mathrm{H}$. M a r k i e w i c z w artykule $O$ polskiej literaturze z kluczem (w: Prace wybrane. T. 2: Z historii literatury polskiej. Kraków 1996, s. 361).

34 Zob. przede wszystkim T. S. C h e s z c z y k, Lakmusowy papierek. „Po Prostu” 1955, nr 11. 
Konrad Górski. Dziekan Wydziału Humanistycznego, profesor Gleb, to Kazimierz Hartleb. Sekretarz Komitetu Wojewódzkiego PPR Faber - to Antoni Alster, w okresie 1945-1947 sekretarz Komitetu Wojewódzkiego PPR w Bydgoszczy (później zaś, w latach 1954-1956, zastępca przewodniczącego Komitetu do spraw Bezpieczeństwa Publicznego, a następnie - do 1962 r. - wiceminister w Ministerstwie Spraw Wewnętrznych; wiązano go z tzw. grupą puławską).

Doktor Cybajtisowa to Maria Puciatowa, pracownik, a od 1955 r. dyrektor Biblioteki Głównej Uniwersytetu Mikołaja Kopernika ${ }^{35}$. Magister Ławrynowicz to Włodzimierz Hołubowicz, archeolog, starszy asystent w Katedrze Prehistorii (następnie - od 1951 r. - profesor w Katedrze Archeologii Polski Uniwersytetu Wrocławskiego). Doktor Stolarczyk to Tadeusz Cieślak, historyk, adiunkt w Katedrze Historii Powszechnej Państwa i Prawa, w roku akademickim 1948/49 także dyrektor administracyjny UMK, od r. 1952 pracował poza Toruniem (m.in. w latach 1955-1961 był rektorem Szkoły Głównej Służby Zagranicznej).

Pierwowzorem Zbyszka Wójcika jest sam autor powieści (świadczą o tym tożsame inicjały, służba wojskowa przed podjęciem studiów). Jerzy Barenda zaś to Jerzy Zaremba, działacz AZWM i PPR (PZPR), I sekretarz KU PZPR w latach 1947-1950, młodszy asystent w Katedrze Nauki o Państwie i Prawie.

Sprawa komplikuje się w wypadku profesora Nierojewskiego; wydaje się, że autor obdarzył go pewnymi elementami biografii ówczesnego rektora UMK, Ludwika Kolankowskiego (choć równocześnie przedstawił go jako powieściowego rektora Kroguleckiego). Nierojewski wywodzi się - podobnie jak Kolankowski - z Uniwersytetu Jana Kazimierza we Lwowie i zajmuje się stosunkami polsko-rosyjskimi, te zaś stanowiły główny przedmiot zainteresowań naukowych rzeczywistego rektora UMK (był on m.in. autorem monografii Polska Jagiellonów. Dzieje polityczne, ogłoszonej w r. 1936) ${ }^{36}$. Kolankowski natomiast nie wykładał w czasie okupacji na Uniwersytecie im. Iwana Franki; tu pisarz obdarzył Nierojewskiego elementem biografii następcy Kolankowskiego na stanowisku rektora UMK, Karola Koranyiego (który w latach 1939-1941 i 1944-1945 był profesorem Uniwersytetu im. Iwana Franki). Tropy są wyraźnie celowo splątane: powieściowy Stolarczyk jest uczniem Kroguleckiego (a zatem - Kolankowskiego), rzeczywisty Cieślak wydoktoryzował się pod kierunkiem Koranyiego. Środowiskowa plotka ${ }^{37}$ natomiast utożsamiała Nierojewskiego z historykiem Karolem Górskim, uczonym współpracującym z Duszpasterstwem Akademickim (w okresie międzywojennym związanym wszakże - to kolejny przykład owego mylenia tropów przez autora $\mathrm{z}$ uniwersytetem poznańskim, a nie lwowskim) ${ }^{38}$. Za aluzję do biografii naukowej

${ }^{35}$ Nazwisko tej bohaterki przypomina nazwisko innej osoby związanej na przełomie lat czterdziestych i pięćdziesiątych z UMK: dr Heleny Cynkutisowej, lekarki w ambulatorium UMK.

${ }^{36} \mathrm{~W}$ powieści mówi się, że Nierojewski to twórca tezy o „Polsce od morza do morza” (I 31), Kolankowski zaś w swych publikacjach zajmował się ,ideą jagiellońską”, której sens był zbliżony. Zob. Z. H. N o w a k, Rola Ludwika Kolankowskiego w historiografii polskiej. W zb.: Ludwik Kolankowski 1882-1982. Materiaty sesji w stulecie urodzin. Red. A. Tomczak. Toruń 1983, s. 29.

${ }^{37}$ Informację tę zawdzięczam Z. J ę d r zy ń s k i e m u (rozmowa telefoniczna z 30 V 2011).

${ }^{38} \mathrm{Na}$ temat związków K. Górskiego z Duszpasterstwem Akademickim zob. C. I w a n i s z e ws k a, ,,Synowie twoi jak gałazki oliwne dookoła twego stołu”. Poczatki Duszpasterstwa Akademickiego w Toruniu. W zb.: Jezuici w Toruniu 1596-1996. Materialy z konferencji zorganizowanej w Toruniu 17-23 listopada 1996 z okazji Jubileuszu 400-lecia przybycia Jezuitów do miasta. Red. K. Maliszewski, W. Rozynkowski. Toruń 1997, s. 129. 
Górskiego można uznać fakt, że Nierojewski zajmuje się wyprawami krzyżowymi (zob. I 30); Górski był wszak wybitnym badaczem dziejów zakonu krzyżackiego (którego geneza wiąże się ze średniowiecznymi krucjatami) ${ }^{39}$.

Powieść została odczytana przez część środowiska toruńskiego jako paszkwil na nie. Wróblowi przypisywano złe intencje, a sytuację dodatkowo komplikował fakt, że był on szwagrem Jerzego Zaremby (autor Inauguracji ożenił się z Heleną Zarembianką, na przełomie lat czterdziestych i pięćdziesiątych studentką polonistyki). W przywołanym już reportażu tajemniczy T. S. Cheszczyk (jest to bez wątpienia pseudonim) rekonstruuje stanowisko przeciwników Wróbla i jego powieści:

A więc cała książka została napisana po to, by bronić „rodzinki” autora, a odegrać się na dawnych przeciwnikach byłego sekretarza. A więc - jest to faszystowska książka - bo chodzi o rozgrywki personalne, bo Stolarczyk - w którym prof. Cieślak odszukał siebie, to postać negatywna, a Barenda - rzekomy szwagier autora - to postać pozytywna, podczas gdy w rzeczywistości było odwrotnie itp. Przy okazji nie szczędzono obelg autorowi, nie szczędzono rozmaitych szczegółów z działalności Zaremby w Toruniu, a nawet wręcz pytano się Wróbla, dlaczego nie skorzystał z dokumentów partyjnych, z których niedwuznacznie wynika, kto naprawdę był pozytywny, a kto nie.

\section{Dalej zaś pisze:}

Oj, nie łatwo [!] być autorem książki w Toruniu, nie. Nie wolno ci użyć nazwiska Stolarczyk, bo stolarz i cieśla to pokrewne zawody, nie wolno puścić wodzy fantazji - bo w dokumentach jest inaczej, nie wolno użyć satyrycznego przejaskrawienia - bo stajesz się paszkwilantem $\mathrm{i}$ to do tego faszystowskim ${ }^{40}$.

Autor reportażu (a tym samym - redakcja „Po Prostu”) najwyraźniej stanął po stronie Wróbla i jego powieści (broniono w ten sposób swego niedawnego kolegi, Wróbel był bowiem w latach 1951-1952 redaktorem działu kulturalnego tego ZMP-owskiego tygodnika). Można wszakże sądzić, iż bliżsi prawdy byli przeciwnicy powieści, twierdzący, że Inauguracja to paszkwil - i to dość prymitywny - na wrogów autora utworu ${ }^{41}$.

39 Zob. M. B i s k u p, Karol Górski-tradycyjny czy nowatorski badacz dziejów zakonu krzyżackiego. W zb.: Karol Górski-człowiek i uczony. Red. Z. H. Nowak. Toruń 1999.

${ }^{40} \mathrm{C}$ h e s z c zy k, op. cit., s. 1 . Z partyjnych dokumentów wynika, że w organizacji PZPR-owskiej istniały dwie grupy: „klika” Zaremby i Hołubowicza (czyli Barendy i Ławrynowicza) oraz grupa Cieślaka (czyli powieściowego Stolarczyka); o tej pierwszej czytamy, iż „charakteryzuje [ją] kapralski, ostry stosunek do ludzi, czym partia sobie zraziła wielu ludzi, asystentów i profesorów. Partia jest wskutek tego niepopularna" (Powstanie i pierwsze dziesięć lat Uniwersytetu Mikołaja Kopernika 1945-1956, s. 213). J. S e r c z y k (Wspomnienia z pierwszych lat uniwersyteckich 〈1947-1950〉. W zb.: Uniwersytet Mikołaja Kopernika. Wspomnienia pracowników. Red. A. Tomczak. Toruń 1995, s. 245), nieżyjący już profesor UMK, a na przełomie lat czterdziestych i pięćdziesiątych student historii, pisał we wspomnieniach, że Zaremba „był [...] na Uniwersytecie praktycznie drugą osobą po rektorze, a w pewnych kwestiach nawet pierwszą". Na temat personalnego klucza w Inauguracji zob. też: A. L e w a n d o w s k i, Pro memoria. W zb.: Uniwersytet Mikołaja Kopernika. Wspomnienia absolwentów. Plon Konkursu ogłoszonego w 2008 r. przez Stowarzyszenie Absolwentów UMK. Toruń 2009, s. 41.

${ }^{41}$ Z przeciwnikami powieści solidaryzował się recenzent ,Trybuny Ludu”, L. G o 1 iń s k i ( $\mathrm{Na}$ marginesie nowej studenckiej powieści. „Trybuna Ludu” 1955, nr 90, s. 4): „Jeśli autor znanych sobie i innym bohaterów przedstawia na kartach książki w sposób wykluczający omyłki, a zarazem czyni z nich, już z przyczyn konstrukcyjnych powieści, dla własnej wygody - ludzi godnych pogardy, nikczemnych moralnie i obłudnych politycznie, bo takiego właśnie »bohatera« wymaga w tym 
Inaczej - w perspektywie genezy - przedstawia się sprawa z Herkulesami; autor nie jest tu związany z opisywanym środowiskiem. Utwór nie stanowił wszakże efektu tzw. akcji terenowej ${ }^{42}$, lecz powstał w wyniku pewnego zbiegu okoliczności. Stawiński tak wypowiadał się na ten temat w 1953 roku:

Przyjechałem do Białegostoku na krótki wypoczynek, zetknąłem się z Akademią. To bardzo piękna uczelnia. Szybko rosną tam ludzie, szybko dojrzewają. Zostałem więc dłużej, by napisać o tych przemianach ${ }^{43}$.

\section{W roku 2000 pisał o tym szerzej:}

Tadeusz Rogalski, mój kolega z warszawskiego gimnazjum im. ks. Józefa Poniatowskiego, zaprosił mnie w roku 1951 do Białegostoku, twierdząc, że mieszka w pałacu. [...] Okazało się, że mianowano go dziekanem wydziału lekarskiego w powstającej właśnie Akademii Medycznej. Rzeczywiście mieszkał w świeżo odbudowanym skrzydle pałacu Branickich, siedzibie Akademii. [...] Jeżeli można mówić o pozytywnych decyzjach w okresie stalinowskim, to za jedną z najlepszych należy uznać powołanie Akademii Medycznej w Białymstoku, zacofanym i rolniczym regionie Polski. Posągi Herkulesów, wieńczące wjazd do pałacu, nadawały całemu przedsięwzięciu majestatyczną rangę.

Kolega Rogalski zaprosił mnie nie tylko z przyjaźni, ale i z myślą, że zbiorę tu jakiś materiał do reportażu. Byłem, ,potencjalnym” literatem w okresie najmniej do twórczości sposobnym, gdyż w roku 1951 obowiązywał realizm rzeczywistości nie takiej, jaka jest, ale jaka być powinna według żdanowowskiej estetyki. Żeby wydać książkę, należało w niej odpowiednio nałgać. Jak dalece nałgać?

Widok był socrealistyczny: w odbudowanym przez władzę ludową magnackim pałacu uczy się wiedzy medycznej młodzież chłopska z zacofanych dotąd wsi, a Akademia rozjaśnia mrok, pozostawiony przez kapitalistyczno-obszarniczą, przedwojenną Polskę. Tytuł nasunął mi się od razu: Herkulesy ${ }^{44}$.

Akcja powieści rozpoczyna się jesienią 1950, a zatem w pierwszym roku istnienia uczelni.

We wstępnych scenach oglądamy miasto oczami głównego, pozytywnego bohatera, Józka Gandery. Odnajdujemy w opisie charakterystyczny dla literatury tamtych lat kontrast nowego ze starym. Oto widok odbudowywanego po wojennych zniszczeniach centrum ${ }^{45}$ :

Wszystkie domy dwupiętrowe. Tutaj, na wprost gospody, tynkują właśnie nowy, reprezentacyjny budynek. Naprzeciwko wielki, piękny gmach, już wykończony: bank. A dalej czerwone bloki osiedla mieszkaniowego tworzą nową ulicę. Osiedle jest już zamieszkałe, choć brak jeszcze tynków. Tynki zmienią zapewne jego wygląd. Na razie czerwień cegły nadaje mu piętno monotonii. [H 20]

Tak wygląda „nowe”. W bezpośrednim sąsiedztwie Gandera dostrzega wszak-

miejscu fabuła - trudno się dziwić, że »rozszyfrowani« w ten sposób żywi ludzie mają mu to za złe. To nie jest sprawa konwencji literackiej, to jest fotografizm w złym znaczeniu tego słowa. Nikogo nie wolno oczerniać, nawet jeśli przekręci się lub wręcz zmieni jego nazwisko, mimo to bliżsi i dalsi znajomi nie mają trudności z »uterenowieniem « powieści i »umiejscowieniem《 jej bohaterów”.

${ }^{42} \mathrm{Na}$ temat akcji terenowej zob. M. Z a w o d n i a k, Teraźniejszość i przeszłość. Studia o życiu literackim socrealizmu. Bydgoszcz 2007, s. 105 n.

43 J. S. S t a w iń s k i, Medycy o „Herkulesach”. „Po Prostu” 1953, nr 24, s. 4.

${ }_{44}$ J. S. S t a w i ń s k i, Komentarz do książki ,Herkulesy”. W zb.: Pót wieku Akademii Medycznej w Biatymstoku 1950-2000, s. 112-113.

${ }^{45}$ Miasto uległo zniszczeniom i w czerwcu 1941, po rozpoczęciu wojny niemiecko-sowieckiej, i w lipcu 1944, w czasie ofensywy Armii Czerwonej. Zob. D o b r oń s k i, op. cit., s. 168, 179. 
że „stare”: „Są kocie łby i parterowe drewniaki, brązowe jakieś albo zielone” (H 21). W powieści pokazane zostają i ów kontrast, i walka „nowego” ze „starym”:

kontrast jest rażący. Miasto, nowe miasto wznoszone z gruzów w tempie nie znanym dotąd jego mieszkańcom, nowoczesne, murowane i czyste - i o dwieście kroków miasto-zabytek, zbiorowisko parterowych brzydkich domów, brudnych, nie skanalizowanych, ciasnych, cuchnących.

Nowe miasto naciera. Przypuściło atak tą ulicą z parkanami [...]. Czerwień cegieł zbliża się do drewniaków, grozi, zwiastuje im klęskę. [H 21]

Podkreśla się też, że tworzenie akademii w Białymstoku miało znamiona działalności pionierskiej. Jeden z pozytywnych bohaterów mówi:

Wiecie, co to znaczy puścić w ruch nową uczelnię. Tak od razu, w ciągu paru miesięcy? W mieście, które nie ma fachowców, gdzie wszyscy pracują powoli, ruszają się powoli... [H 72]

Sytuacja, w jakiej znajdowała się nasza akademia, była zupełnie specjalna. Stworzono na nowym terenie, terenie dotąd zacofanym, uczelnię dla ludu, dla synów robotniczych i chłopskich. Z całej Polski przybyli tu studenci, ze wszystkich klas społecznych. [H 135-136]

Autor koncentruje się na środowisku studentów; niemal całkowicie pomija kadrę dydaktyczną ${ }^{46}$ (co wytknięto mu w wielu recenzjach, traktując jako mankament powieści ${ }^{47}$ ). Kładzie przy tym duży nacisk na zróżnicowanie społeczne młodzieży. Główna postać, Józek Gandera, to syn chłopa mającego 5-hektarowe gospodarstwo ${ }^{48}$; inny pozytywny bohater, Wiśniewski, to syn śląskiego robotnika. Oprócz dzieci z takich rodzin studiują także młodzi ludzie z domów mieszczańskich $\mathrm{i}$ inteligenckich (narrator skrupulatnie informuje o rodowodzie bohaterów: Danusia Niezabitowicz pochodzi z rodziny drobnomieszczańskiej ${ }^{49}$, ojciec Danikowskiego był przed wojną dyrektorem fabryki, itd.). Na tym tle pojawiają się w powieści konflikty, stanowiące namiastkę walki klasowej, ale nie mają one zasadniczego znaczenia dla przebiegu fabuły (choć wyrażenie „walka klasowa” często występuje w wypowiedziach bohaterów). Owo upodrzędnienie walki klasowej rozmaicie było oceniane przez recenzentów książki; autorka jej omówienia w „Trybunie Ludu” twierdziła, że pisarz ,zgubił wroga klasowego” i - rzecz jasna - uwa-

${ }^{46}$ Reprezentantem grona naukowców najczęściej pojawiającym się w powieści jest rektor, lecz i o nim dowiadujemy się jedynie, że jest ,wysoki, dziwnie młody” (s. 30) oraz „szczupły i ma ujmujący uśmiech" (s. 83). T. Kielanowski miał wówczas 45 lat.

47 Zob. np. K. S., Książka o naszych studentach. „Życie Białostockie” 1953, nr 117, s. 6. B. D u d z iń s k i, Powieść z życia młodzieży studenckiej. „Głos Pracy” 1953, nr 203, s. 4. Zarzucano też Stawińskiemu, że pomija „starcia światopoglądowe w dziedzinie biologii” (czyli walkę z przeciwnikami teorii T. Ł y s e n k i) - zob. H. K i r c h n e r, Oczekiwane spotkanie. „Nowa Kultura" 1953 , nr 23, s. 7.

${ }^{48}$ Fakt, że ojciec bohatera to tzw. chłop średniorolny (,średniak”), ma znaczenie ze względu na fabułę utworu. Jest w niej bowiem - mniej dla nas interesujący - wątek wiejski, gdzie odnajdujemy motyw typowy dla wiejskiego nurtu prozy socrealistycznej: stary Gandera - jako „średniak” - waha się, czy przystąpić do spółdzielni produkcyjnej (syn - rzecz jasna - go do tego zachęca).

49 Warto wspomnieć o jej lekturach; czyta ona Trędowata H. Mniszkówny, powieści A. Christie, ale też Duszę zaczarowana R. Rollanda. P ę d z i ń s k i (op. cit., s. 5) w recenzji Inauguracji W rób 1 a zwracał uwagę na podobieństwo Luśki Putkówny do Danki Niezabitowicz: ,,medyczka Danusia z Herkulesów przedzierzga się w historyczkę Lusię w Inauguracji - zmieniając jedynie miejsce zamieszkania, legitymację i indeks - nie zmieniając natomiast ani rodziny, ani sposobu uwodzenia chłopaków, ani stylu życia (może jest odrobinkę bardziej »kociakowata«)". 
żała to za wielki mankament utworu ${ }^{50}$. Podobną opinię formułował Bronisław Gołębiowski:

Problem walki klasowej w Herkulesach jest zepchnięty na boczne tory. Odbywa się walka z chuligaństwem, sobkostwem, przede wszystkim na płaszczyźnie moralno-obyczajowej. Politycznej i ideologicznej ofensywy wroga nie widać ${ }^{51}$.

Byli wszakże recenzenci, którym ów brak klasowych konfliktów nie przeszkadzał, chwalili zaś w powieści wierny obraz uczelnianej codzienności:

Realia u Stawińskiego konstytuują się w specyficzny klimat, własną atmosferę uniwersyteckiego życia, wyznaczają jego rytm. Tak jak być winno w powieści środowiskowej.

$[\ldots]$

Jest dużą zaletą powieści Stawińskiego potoczność, codzienność zawartego w niej doświadczenia ${ }^{52}$.

Główny konflikt w Herkulesach związany jest z faktem, że źle działa uczelniane koło ZMP. Na jego czele stoi student Sapiński, który kieruje się własnymi egoistycznymi interesami i stosuje ,zamordystyczne” metody, w czego efekcie cierpią pozytywni bohaterowie. Jego postępowanie wzbudza wszakże sprzeciw studenckiego kolektywu; Sapiński ponosi porażkę i postanawia opuścić uczelnię. Po krótkim czasie decyduje się jednak na powrót, przechodzi niemalże cudowną metamorfozę (wbrew psychologicznemu prawdopodobieństwu) i staje się wzorowym studentem i działaczem.

Po latach Stawiński tak komentował fabułę powieści:

Rozmawiałem dużo ze studentami. Szczególnie zainteresował mnie jeden, sympatyczny i rozgarnięty chłopski syn z okolic Białegostoku, który na studia wstąpił z prawdziwym entuzjazmem. [...] Niestety! Mój student nie miał czasu się uczyć. Przyjęty na studia z rekomendacji ZMP, młodzieżowego ramienia PZPR, musiał temuż ZMP spłacać dług wdzięczności. Odbywał wielogodzinne zebrania-nasiadówki, wysyłano go w teren na niezliczone akcje i mój pozytywny bohater, nie śmiejąc odmówić ze strachu, zawalał naukę.

[...] Jak każdy przeciętny Polak nie kochałem stalinizmu, postanowiłem więc napisać o jego „wypaczeniach”. Napisałem więc, jak było naprawdę: ZMP wykańcza swoich co zdolniejszych członków. Maszynopis złożyłem w Wydawnictwie, które zareagowało tak, jak można było przewidzieć: jeżeli coś krytykujesz, to bardzo dobrze, krytyka jest nam potrzebna jak powietrze, ale jednocześnie w trosce o socjalistyczny rozwój musisz wskazać drogę naprawy błędów, bo przecież to nie ustrój jest winny, tylko miejscowe ZMP dopuściło się wypaczeń. Po prostu chłopaki przegięły pałę. I tak powstała książka, złożona z dwóch części: pierwsza zawierała nieśmiało wyjawioną prawdę, a druga - całkowite łgarstwo, gdzie czarny charakter (przewodniczący uczelnianego ZMP) staje się aniołem, a mój bohater ku powszechnej radości zabiera się do nauki i staje się nie tylko wzorowym aktywistą ZMP, ale i przodującym studentem. Niestety, nie był to Herkules z granitu, ale z papieru ${ }^{53}$.

${ }^{50}$ Z. K w i e c i ń s k a, Ugór jeszcze nie przeorany. „Trybuna Ludu” 1953, nr 118, s. 4.

51 B. G ołę bi ow ski, Powieść o studentach białostockiej uczelni. „Wieś” 1953, nr 21, s. 4. W utworze Stawińskiego pojawia się motyw bójek studentów medycyny z białostockimi chuliganami, tego typu zajścia zdarzały się istotnie w rzeczywistości (zob. np. K. O d y n i e c, Z odległych studenckich wspomnień. W zb.: Pół wieku Akademii Medycznej w Białymstoku 1950-2000, s. 121).

${ }_{52}$ L. F 1 a s z e n, „Herkulesy” - bez Herkulesa. „Życie Literackie” 1953, nr 20, s. 9.

${ }^{53} \mathrm{~S}$ t a w i ń s k i, Komentarz do ksiązki „,Herkulesy”, s. 113. O losach owego przewodniczącego tak pisał - z perspektywy 30 lat - pierwszy rektor białostockiej akademii, prof. K i e l a n o w s k i (op. cit., s. 318): „Okazało się, że jest wśród miłej i dobrej młodzieży zły duch, student M. Kolegów 
Puenta jest optymistyczna. Przytoczmy wewnętrzny monolog najważniejszego pozytywnego bohatera, Józka Gandery:

Na przyszły rok przyjdą nowi studenci, Gandera będzie wtedy na drugim roku - na drugim roku medycyny! - i wykończą dom akademicki. Powstaną nowe zakłady, kliniki... Akademia będzie rosnąć i dojrzewać razem z Ganderą, a jeżeli dobrze pójdzie - musi pójść dobrze! otrzymają dyplomy lekarskie z bardzo niskim numerem, pierwsze dyplomy tej akademii. [H 298-299]

Stawiński nie cenił omawianej powieści. Z perspektywy lat określił swe dwa pierwsze utwory - Światło we mgle i Herkulesy - mianem „półschematycznych powieści dla starszej młodzieży, półzdatnych do czytania z racji pewnych związków z rzeczywistością tamtych lat” ${ }^{54}$. W cytowanym już Komentarzu do ksią̇ki ,,Herkulesy” podsumował: „,był to pół-reportaż, dość niechlujnie wystukany na maszynie: dopiero uczyłem się pisać" ${ }^{55}$. Ci wszakże, którzy znali ówczesne realia z autopsji, skłonni byli powieści Stawińskiego bronić. Dzierżykray-Rogalski, na początku lat pięćdziesiątych dziekan Wydziału Lekarskiego białostockiej akademii, stwierdzał po latach:

Opisał ją [tj. młodzież studiującą na akademii] z dużą wnikliwością Jerzy Stefan Stawiński w powieści-produkcyjniaku pt. Herkulesy [...]. Co by się nie dało powiedzieć o tej książce, to zarówno wybór postaci, ich problemów i postaw był autentyczny. Pod tym względem produkcyjniak Stawińskiego, debiutującego wówczas, a dziś jednego z czołowych literatów, jest dokumentem ${ }^{56}$.

Jeśli zatem w Herkulesach - przywołuję sformułowanie, które Tadeusz Konwicki odniósł do swej Władzy - ,przetrwało trochę prawdy w nieprawdzie" ${ }^{57}$, to jest już, zważywszy na ówczesne warunki, niezaprzeczalny sukces autora. Nie bez kozery Zdzisław Pędziński, porównując dwie zajmujące nas powieści, napisał, że utwór Stawińskiego przynosi pełniejszy obraz ówczesnej rzeczywistości niż Inauguracja Wróbla ${ }^{58}$.

\footnotetext{
i koleżanki terroryzował, podając się za męża zaufania i tajnego informatora jakichś ważnych władz, ale namawiał ich jednocześnie do nieposłuszeństwa wobec władz uczelni, bano się go, strachliwsi pozwalali nawet na rewidowanie swoich walizek. Kiedy doszły do mnie wiadomości, wezwałem go i poprosiłem o wyjaśnienie: próbował i mnie straszyć, ale ja już miałem informację skąd należy, że M. nikogo nie reprezentuje, skorzystałem więc z faktu, że miał ogromne zaległości w studiach, skreśliłem go z listy studentów. Niebawem przyjechali i przyszli do mnie jego zacni, zmartwieni rodzice i... zapłakany M. i dowiedziałem się, że zupełnie podobnie zachowywał się już jako student innej wyższej uczelni, skąd relegowano go za takie same [!] wykroczenie dyscyplinarne. Nie zmieniłem decyzji. Całą sprawę opisał pisarz i autor wielu filmów Jerzy Stawiński w powieści Herkulesy, ale w powieści jest happy end, negatywny bohater wraca na drogę cnoty. Tak było istotnie w kilku innych wypadkach kłopotów wychowawczych ze studentami białostockiej Akademii, ale nie w tym".

54 J. S. S t a w i ń s k i, Notatki scenarzysty. Wyd. 2, uzup. Warszawa 1988, s. 5.

55 S t a w iń s k i, Komentarz do ksiązki ,Herkulesy”, s. 113.

${ }^{56} \mathrm{D}$ z i e r ż y k ra y - R o g a l s k i, Pierwszy rok Akademii Medycznej w Białymstoku, s. 311. Podobną opinię formułował jeden $\mathrm{z}$ recenzentów powieści: „Wszystkie postacie zaczerpnięte są z żywych prawdziwych sylwetek studentów Akademii, i to tak dokładnie scharakteryzowane, że każdy spośród opisanych odnajduje z łatwością siebie mimo pozmienianych nazwisk" (K. S., op. cit., s. 6).

${ }^{57}$ T. Ko n w i c k i, Kalendarz i klepsydra. Warszawa 1976, s. 82.

${ }^{58} \mathrm{P} e ̨ \mathrm{~d}$ zińs ki, op. cit., s. 5.
} 
Abstract

JERZY SMULSKI

(Nicolaus Copernicus University, Toruń)

TWO FORGOTTEN UNIVERSITY NOVELS. A CONTRIBUTION TO THE HISTORY OF SOCIAL REALISM IN POLAND

The article touches upon two university novels written in the first half of the fifties in the $20^{\text {th }}$ century, namely Jerzy Stefan Stawiński's Herculeses (Herkulesy, 1953) and Zdzisław Wróbel's Inauguration (Inauguracja, 1954). The author of the article shows the novels' community character (elements of so-called personal key) and their close connections with socialist realism doctrine. Comparing the two novels, the author concludes that Stawiński's novel, though faithful to the then writing models, contains a more genuine picture of reality of those days. 